\title{
LPAR3 Gene
}

National Cancer Institute

\section{Source}

National Cancer Institute. LPAR3 Gene. NCI Thesaurus. Code C112084.

This gene is involved in calcium mobilization. 